\title{
Modern financial statements too complicated to managers and laymen - a critical survey
}

\author{
J.M. Language \\ Department of Business Management, University of Transkei, Umtata
}

\begin{abstract}
This article is an attempt at scrutinizing accounting practice in South Africa. Firstly, the author demonstrates that the Company Law in South Africa is fairly vague regarding the format and formulation of financial statements. Questions regarding the general use of terms, and more specifically 'generally accepted practice', are raised. Finally, the author discusses some unacceptable aspects of recent presentation of accounting statements.

S. Afr. J. Bus. Mgmt. 1985, 16: $40-45$
\end{abstract}

Hierdie artikel is ' $n$ poging om die huidige rekenmeesterspraktyk krities te ondersoek. Die skrywer toon eerstens aan dat die Maatskappyewet in Suid-Afrika redelik vaag is oor die samestelling of formaat van finansiële jaarstate. Vrae word gestel na algemene terme en die sogenaamde 'algemeen aanvaarde praktyk'. Laastens word onaanvaarbare aspekte van die hedendaagse voorstelling van rekenkundige state krities bespreek.

S.-Afr. Tydskr. Bedryfsl. 1985, 16: $40-45$

\author{
J.M. Language \\ Department of Business Management, University of Transkei, \\ Private Bag X5092, Umtata
}

\section{A brief historical survey of bookkeeping}

The art and science of correctly recording in books of account all those business transactions that result in the transfer of money or money's worth, appear to have existed in a crude state from very ancient times. 'Venice, however, is considered to be the birthplace of the modern system' (Wulfsohn \& Carter, 1947:1).

'In 1494 or 1495, Lucas Pacioli, a Franciscan monk, otherwise known as Lucas de Burgo and Lucas di Borgo, published in Italian the first known treatise on book-keeping. It was entitled De Computis et Scripturis. . . Venice, Genoa and other towns of Italy were the first to practise bookkeeping by double entry ... Pacioli's work was translated into English by Hugh Oldcastle and published in London in 1543. James Peele wrote in 1553 a work on How to keep a Perfect Accompte of Debitour and Creditour. In 1795 Edward Jones published his English System of Bookkeeping which introduced two columns into the Journal instead of one as formerly, the Trial Balance, and the Bought and Sold Day Books ... Modern additions are the Double Account System, the accounts of Joint Stock Companies, the Tabular System and Ledger balancing by means of aggregate accounts (Control Accounts) or "Self-balancing Ledgers". (Wulfsohn \& Carter, 1947)

Nowadays a terminological difference is drawn between the bookkeeper and the accountant. The bookkeeper is thought of as the person who attends to the actual routine or clerical duties relevant to the keeping of the books, whereas the accountant is thought of as the functionary who co-ordinates all the information revealed by the subsidiary books and moulds this information into meaningful accounting statements. During the last few decades management accounting has been evolved to assist management with information for managerial decision-making and control.

Relative silence of the Companies Act regarding the construction or actual format of annual financial statements

Neither the Companies Act No. 46 of 1926 nor the Companies Act no. 61 of 1973 express themselves specifically and explicitly on the actual layout, construction, or format of the annual accounting statements. By annual accounting statements one has in mind the trading account, the profit and loss account (alias income statement) and the balance sheet (Government Printer, 1941 \& 1973).

The main concern of both acts was to ensure that for the sake of interested parties: 
(i) In the case of the 1926 Act, the profit and loss account .... the account reflects a true statement of the profit and loss or income and expenditure, as the case may be, for the period concerned' and as regards the balance sheet '. . . it shall be drawn up to exhibit a true and correct view of the company's state of affairs as at the date of the balance sheet ...'

As regards the terms 'true statement' and 'true and correct view' in the above provisions of the 1926 Companies Act, it should be noted that subsequent amendments to the Act introduced a change in terminology.

According to Henochsberg \& Fairbairn (1953:241), the words 'true and fair view' were introduced in Section 74 of Act No. 46 of 1952 to replace the words 'true' and 'true and correct view' as they appeared in the 1926 Companies Act as amended.

(ii) In the case of Companies Act No. 61 of 1973 the idea of ' . . conformity with generally accepted practice ... ', generally accepted accounting practice (GAAP) was introduced in order to ' . . f fairly present the state of affairs of the company and its business as at the end of the financial year concerned . . ' (Schoeman, 1973).

The relevant sections in the 1973 Act read as follows: '286(3) The annual financial statements of a company shall, in conformity with generally accepted practice, fairly present the state of affairs of the company and its business as at the end of the financial year concerned and the profit and loss of the company for that financial year and shall for that purpose be in accordance with and include at least the matters prescribed by Schedule 4 in so far as they are applicable, and comply with any other requirements of this Act.

286(4)(a) Any director or officer of a company who fails to take all reasonable steps to comply or to secure compliance with the provisions of this section or with any other requirements of this Act as to matters to be stated in annual financial statements, shall be guilty of an offence'.

Section 90 of the 1926 Companies Act (as amended) and Schedule 4 of the 1973 Companies Act, spell out what specific items should at least be included or disclosed in the financial statement but as regards the mould or format these statement should assume, the Act is silent.

\section{The jumping about with terms}

From the above it appears that the legislators have diluted their terminology as regards the general requirements of annual financial statements. In particular, they have shied away from the requirement 'true and correct view'. By the 1952 amendment of Section 90 of the Companies Act, one finds the word 'correct' dropped. At that stage, the word 'fairly' superseded the word 'correct' and from that point of time one had the situation that books of account and annual accounting statements had to be 'true and fair' as regards their reflection of the state of affairs of the company.

The 1973 Companies Act went further and dispensed with the requirement 'true'. Instead, the 1973 Act by introducing the terms 'fairly present' became more general and coined a term of which the interpretation could become a debatable point. As regards these different terms, a considerable measure of jumping about on the part of the legislators was exercised. The implication is not that the choice of the requirement 'fair' was not a good one. On the contrary, the term 'fair' can be regarded as reasonable from the point of view of the practitioner ' . . . since most accounts depend in part upon valuations which in the nature of things are largely a matter of opinion, and are affected by economic circumstances beyond the control of the direction of any one enterprise' (Bray \& Sheasby, 1947).

\section{The terms 'true', 'correct', and 'tair'}

Obviously, what is not true, is false. Also what is not correct is incorrect or wrong, that is, not free from faults. Apparently what prompted the minds of the legislators was that audited accounting statements could not be free from faults in the absolute and therefore the norm of 'fairly' presenting the state of affairs of the company was regarded more proper and reasonable. The word 'fair' could have several meanings but in the context of the Act it would appear that the annual financial statements, seeing that they probably cannot or need not be 'true and correct', are required to be a pretty good or reasonable and acceptable reflection of the financial performance and situation of the company. In its struggle with the obscurity of what comprises 'fair presentation' of accounting statements, the Act finds itself having to hasten for shelter to a somewhat vague concept, namely, that of '... generally accepted accounting practice...' (Schoeman, 1973).

\section{The question of generally accepted accounting practice}

An Accounting Practices Board was established some time ago but the author could not trace the exact date on which this Board came into being. This Board probably came to be reorganized subsequent to the 1973 Companies Act.

'The Accounting Practices Board consists of representatives of the National Council of Chartered Accountants (SA), The Public Accountants' and Auditors' Board, the Johannesburg Stock Exchange, the Association of Chamber of Commerce of South Africa, Die Afrikaanse Handelsinstituut, The South African Federated Chamber of Industries, The Chamber of Mines of South Africa, and the Steel and Engineering Industries of South Africa.

Statements of standard accounting practice are drafted by the National Council of Chartered Accountants (SA) and then submitted to the Board for consideration and, if approved, authorized for issue. The definitive, preferred or alternative accounting treatments set out in statements issued under the authority of the Board are considered generally accepted accounting practice' (National Council of Chartered Accountants, 1978).

The Accounting Practices Board (APB) thereafter issued a series of statements on what they regarded as generally accepted accounting practices. These statements covering Sections 1.001-1.007 and issued during 1974, 1975, and 1976, elaborate such aspects as disclosure of accounting policies, the treatment of taxation in the financial statements, the treatment of extraordinary and/or abnormal items, and guidelines for the determination of earnings per share in an attempt to ensure a fair and comparative base for evaluating current results.

The important point to keep in mind is that despite the numerous illuminations of the Accounting Practices Board, this Board nowhere prescribes any form or structure with which the various annual financial statements should comply. Under section 1.003 an appendix is attached to illustrate the treatment . ... of extraordinary items and prior year 
adjustments' (National Council of Chartered Accountants, 1978).

Worthy of note is the fact that this particular appendix is for general guidance and does not form part of the Statement.

The significance of this veritable illustration to the accounting profession is that arithmetically at least the sequence of treating the figures is from the top to the bottom which is logical.

According to an insert circular issued to the accounting profession dated February 1978, the Accounting Practices Board (1978) sought Senior Counsel's opinion on two important questions concerning the problem of generally accepted accounting practice.

The first question was whether compliance with statements of generally accepted accounting practice (GAAP), issued by the $\mathrm{APB}$, constitute compliance with the GAAP requirements of the Companies Act 1973?

According to the relevant circular or so-called statement issued by the Accounting Practices Board during February 1978 '. . . Senior Counsel is of the opinion that, having regard to the procedure adopted by the APB in considering and approving GAAP statements and the composition of the $\mathrm{APB}$, that to the extent that a company in drawing up its financial statements complies with, and an auditor in carrying out his duties follows, a statement of the APB they 'can safely assume that they have complied with the provisions of the Companies Act in respect of generally accepted accounting practice' (National Council of Chartered Accountants, 1978).

The above opinion of Counsel is fundamentally based on two explicit background conditions or considerations, namely, the procedure adopted by the APB, and having regard to the composition of the APB which appears to be fairly representative of eminent bodies in the field of accounting, finance, and commerce in South Africa.

The second question on which the opinion of Senior Counsel was sought was whether non-compliance with these statements (by the APB) constitute [d] a contravention of the GAAP requirements of the Companies Act, 1973.

It is apparent that the Accounting Practices Board in submitting this second question to the opinion of Senior Counsel sought to clarify, and quite sensibly at that, its own power to prescribe what in actual fact constituted 'generally accepted accounting practice'.

The fact is that in terms of the expressed view of Senior Counsel, the Accounting Practices Board could not have a generally prescriptive right to the accounting profession regarding what in fact constituted 'generally accepted accounting practice'. National Council (1978) expressed itself as follows:

'Senior Counsel expressed the opinion that 'the question whether any particular practice complies with the statutory requirements remains a matter of fact and of professional opinion to be decided upon the merits of each particular case and the existence of an APB statement therefore constituted evidence of what generally accepted accounting was, but need " . . . not necessarily be decisive". It therefore does not necessarily follow that non-compliance with the statements by the APB will constitute a contravention of the requirements of the Companies Act'.

The concept 'generally accepted accounting practice' appears to be an evolutionary rather than a static one. Consequently, the accounting profession seems to be enjoying a wide measure of flexibility and discretion regarding the actual design or composition of annual financial statements provided at least those matters prescribed by the Act are revealed.

'Counsel . . . also pointed out that statements issued by the APB were likely to win growing acceptance from the profession and the business community. Consequently a practice which "today may be regarded as within the limits of the permissible, although it is not in accordance with the statement of the Board, may well within a few years or less be regarded as falling outside those limits" ' (National Council of Chartered Accountants, 1978).

The opinion expressed in the first part of the above comment was perhaps somewhat overoptimistic because the larger auditing firms have in the mean time either adopted their own standardized pattern of presenting financial statements or have issued guidelines to its various offices.

\section{Unacceptable aspects of the modem way of presenting accounting statements}

Whilst the question of what constitutes 'generally accepted accounting practice' appears to be a fluid one and mainly concerns certain legal disclosure requirements, certain aspects of the 'modern' glaringly queer arithmetical system of presenting the actual figures by certain sections of the profession becomes a matter which cannot escape unfavourable comment.

\section{The confusion caused by the traditional T-shaped balance sheet}

The traditional $\mathrm{T}$-shaped balance sheet with liabilities on the left-hand side and assets on the right-hand side was one of the most confusing inconsistencies the accounting profession, particularly in Great Britain and its dominions, including South Africa, ever committed.

The Society of Incorporated Accountants was formed in 1885 in Britain and there is no evidence to suggest that even then the liabilities were not marshalled on the left-hand side and assets on the right-hand side (Bray \& Sheasby, 1947).

'In practice, the liabilities are placed on the left hand side of the Balance Sheet and the assets on the right...'

It should be remembered that the balance sheet is not an account and does not require "Dr." and "Cr." ...

"It is a statement at a given date showing the financial position of a business"' (Hutchinson \& Tunstall, 1926:64).

The illogic of all this is very obvious. The trial balance was extracted from the ledger with debits (including assets) on the left-hand side and credits (including liabilities) on the credit or right-hand side, but when this trial balance was reduced to a net-profit figure and the remainder of the items taken to the balance sheet, the debits and credits were entered crosswise on opposite sides of the balance sheet as if the balance sheet was indeed an account and not a statement.

This piece of undelightful illogic confused and frustrated many a student of accounting and it has immensely complicated teaching of the subject. Confronting the accounting profession for an explanation of this glaring inconsistency invariably elicited the unsatisfactory stock answer that ' . . . this was tradition and an accounting convention'. These frolics of dodging the issues had the effect of making accountants the secret laughing stock of so many over so many decades. It must also have cost the profession and the subject much by way of appeal to prospective students and practitioners alike. 
The quiet withdrawal of the headings 'liabilities' and 'assets' from the balance sheet

The Council of the Institute of Chartered Accountants in England and Wales, 1942-1946, recommended, with reference to accounting principles, that:

'The use of general headings for a balance sheet, such as "liabilities" and "assets" is inappropriate and unnecessary. The various items, whatever may be their sequence or designation, should, however, be grouped ...' (Bray \& Sheasby, 1947:204).

This recommendation heralded the practice of grouping like items under such headings as current liabilities, current assets, fixed assets, etc. However, the various groups of liabilities were still shown on the left-hand side of the balance sheet and the assets on the right.

Although the grouping system was a definite step in the right direction from the point of view of using accounting statements for managerial purposes, the absurdity of listing liabilities on the left-hand side and assets on the right was not removed thereby. Of course, in the United States of America, assets and liabilities are shown on what one might term the 'correct' sides of the balance sheet.

\section{MANUFACTURING COMPANY LIMITED} BALANCE SHEET AS AT $31 \mathrm{MARCH}$ 19X1

\begin{tabular}{|c|c|c|c|}
\hline & Note & $\begin{array}{c}19 \times 1 \\
\mathrm{R}\end{array}$ & $19 \times 0$ \\
\hline CAPITAL EMPLOYED & & $\mathbf{R x x x}$ & Rxxx \\
\hline \multicolumn{4}{|l|}{ EMPLOYMENT OF CAPITAL } \\
\hline Fixed assets & 5 & $\operatorname{xxxx}$ & $\mathbf{x x x x}$ \\
\hline Investment in Subsidiaries & 6 & $\mathbf{x x x x}$ & $\mathbf{x x x x}$ \\
\hline Other Investments & 7 & $\mathbf{x x x x}$ & $\mathbf{x x x x}$ \\
\hline Loan Levy & & $x x x x$ & $\mathbf{x x x x}$ \\
\hline \multirow[t]{2}{*}{ Loans } & & $\mathbf{x x x x}$ & $\operatorname{xxxx}$ \\
\hline & & $\mathbf{x x x x}$ & $\mathbf{x x x x}$ \\
\hline \multicolumn{4}{|l|}{ CURRENT ASSETS } \\
\hline Stock & 8 & $\mathbf{x x x x}$ & $\mathbf{x x x x}$ \\
\hline Accounts Receivable & 9 & $\mathbf{x x x x}$ & $\mathbf{x x x x}$ \\
\hline $\begin{array}{l}\text { Amount owed by group } \\
\text { companies }\end{array}$ & \multicolumn{2}{|c|}{ Amount owed by group } & \\
\hline Funds at call & & $\mathbf{x x x x}$ & $\operatorname{xxxx}$ \\
\hline \multirow[t]{2}{*}{ Bank balances and cash } & & $\mathbf{x x x x}$ & $\operatorname{xxxx}$ \\
\hline & & $\operatorname{xxxx}$ & \\
\hline \multicolumn{4}{|l|}{ CURRENT LIABILITIES AND } \\
\hline \multicolumn{4}{|l|}{ PROVISIONS } \\
\hline Loans & & $\operatorname{xxxx}$ & $\mathbf{x x x x}$ \\
\hline \multicolumn{4}{|l|}{ Accounts payable } \\
\hline Provisions & 11 & $\mathrm{xxxx}$ & $\operatorname{xxxx}$ \\
\hline \multicolumn{4}{|l|}{ Amounts owed to group } \\
\hline Bank overdrafts & & $\mathbf{x x x x}$ & $\operatorname{xxxx}$ \\
\hline \multirow[t]{2}{*}{ Dividends recommended } & 20 & $\mathrm{xxxx}$ & $\operatorname{xxxx}$ \\
\hline & & $\mathbf{x x x x}$ & $\mathbf{x x x x}$ \\
\hline \multirow{3}{*}{$\begin{array}{l}\text { NET CURRENT ASSETS } \\
\text { DEFERRED EXPENDITURE }\end{array}$} & & $\mathbf{x x x x}$ & $\operatorname{xxxx}$ \\
\hline & 12 & $\mathbf{x x x x}$ & $\mathbf{x x x x}$ \\
\hline & & $\operatorname{Rxxx}$ & $\operatorname{Rxxx}$ \\
\hline
\end{tabular}

Figure 1 Specimen balance sheet issued by the National Council of Chartered Accountants (S.A.) during April 1977.
Introduction of the vertical balance sheet in South Africa

In a guideline on annual financial statements issued by the National Council of Chartered Accountants (S.A.) during April 1977 a specimen balance sheet in vertical form was set out. This guideline replaced the previous guidelines, issued February 1975, and statements $\mathrm{Cl}$ and $\mathrm{C} 2$ in the earlier series of technical statements. These earlier statements could not be CONSOLIDATED BALANCE SHEET OF ... CO., LTD.

\begin{tabular}{|c|c|c|c|}
\hline Ordinary share capital & 1 & 7202 & 7202 \\
\hline Share premium & & 21567 & 21567 \\
\hline Non-distributable reserves & 2 & 18759 & 18383 \\
\hline Distributable reserves & 3 & 16822 & 14967 \\
\hline \multicolumn{4}{|l|}{ ORDINARY SHARE- } \\
\hline $\begin{array}{l}\text { PREFERENCE SHARE } \\
\text { CAPITAL } \\
\text { INTEREST OF OUTSIDE }\end{array}$ & 1 & 13417 & 13517 \\
\hline $\begin{array}{l}\text { INTEREST OF OUTSIDE } \\
\text { SHAREHOLDERS }\end{array}$ & 4 & 9895 & 8769 \\
\hline & & 87662 & 84405 \\
\hline \multirow[t]{2}{*}{ Long-term liabilities } & 5 & 30094 & 28688 \\
\hline & & 117756 & 113093 \\
\hline FIXED ASSETS & & 52644 & 53900 \\
\hline Land and buildings & 6 & 35883 & 36083 \\
\hline $\begin{array}{l}\text { Plant, equipment and } \\
\text { vehicles }\end{array}$ & 7 & 15303 & 16157 \\
\hline $\begin{array}{l}\text { Improvements to leased } \\
\text { premises }\end{array}$ & 8 & 189 & 396 \\
\hline Investments & 9 & 1260 & 1260 \\
\hline $\begin{array}{l}\text { Patents and manufacturing } \\
\text { rights }\end{array}$ & 10 & 9 & 4 \\
\hline $\begin{array}{l}\text { INTEREST IN SUBSIDIARIES } \\
\text { INTEREST IN ASSOCIATED }\end{array}$ & 11 & - & - \\
\hline COMPANIES & 12 & 22987 & 20642 \\
\hline LOAN PORTION OF & & & \\
\hline TAXATION & & 1640 & 1602 \\
\hline $\begin{array}{l}\text { NET CURRENT ASSETS } \\
\text { (LIABILITIES) }\end{array}$ & & 40485 & 36949 \\
\hline Current assets & & 95906 & 95313 \\
\hline Stock & 13 & 40868 & 42562 \\
\hline Accounts receivable & 14 & 51117 & 49372 \\
\hline Bank balances and cash & & 3921 & 3378 \\
\hline Current liabilities & & 55421 & 58363 \\
\hline Accounts payable & & 33802 & 32468 \\
\hline $\begin{array}{l}\text { Current portion of long- } \\
\text { term liabilities }\end{array}$ & & 1933 & 5104 \\
\hline Unsecured loans & & 9951 & 13655 \\
\hline Bank overdrafts & & 3102 & 2395 \\
\hline Taxation & & 5347 & 4027 \\
\hline Dividends payable & & 1286 & 714 \\
\hline & & 117756 & 113093 \\
\hline
\end{tabular}

Figure 2 Balance sheet showing the use of the system of boxes in actual practice. 
traced but if they did not suggest the vertical form it can be assumed that the vertical form of balance sheet was presented as a guideline at least not later than April 1977.

The point to note regarding the introduction of the vertical form of balance sheet is that it rescued the accounting world from its dilemma of having to attempt explaining the absurdity of showing liabilities and assets on the 'wrong' sides of the T-shaped balance sheet.

\section{Undesirable features of the modern accounting way of presenting figures}

Figure 1 is a condensed version of guideline No. 4.001 issued by the National Council of Chartered Accountants (S.A.) during April 1977 (National Council of Chartered Accountants, 1978).

In the above format the current assets and the current liabilities have been listed to arrive at a net difference.
Consequently when the other assets at the top of the balance sheet must be added to the net current assets and the deferred expenditure item, one has to do the casting by jumping the inserted portion of the figures. From the arithmetical point of view this system of intermittent figures is quite ludicrous and confusing. In actual practice the system of boxes has been introduced and just to add to the confusion, the practice has been evolved whereby certain figures are added from the bottom to the top whereas others are added from the top to the bottom. An example from actual practice illustrates the point (Figure 2). The figures relate to the financial statements of a very prominent South African firm and are not hypothetical. For obvious reasons the firm's identity is concealed

The eccentric feature about the above format is that whereas as regards the liabilities the figures are added from the top to the bottom, an entirely different pattern is followed when it gets to the assets. Quite contrary to all standards of
Ordinary share capital

Share premium

Non-distributable reserves

Distributable reserves ORDINARY SHARE HOLDERS'/INTEREST
PREFERENCE SHARE CAPITAL

INTEREST OF OUTSIDE SHARE HOLDERS

\section{LONG-TERM LIABILITIES}

FIXED ASSETS

Land and buildings

Plant, equipment and vehicles

Improvement to leased premises

Investments

Patents and manufacturing rights

Interest in subsidiaries

Interest in associated companies

Loan portion of taxation

NET CURRENT ASSETS

Current assets

Stock

Accounts receivable

Bank balances and cash

Current liabilities

Accounts payable

Current portion of long-term liabilities

Unsecured loans

Bank overdrafts

Taxation

Dividends payable
CONSOLIDATED BALANCE SHEET OF . . CO. LTD.

$\begin{array}{ccc} & 1979 & 1978 \\ \text { Notes } & R^{\prime} 000 & R^{\prime} 000\end{array}$

7202

7202

21567

21567

18383

14967

3

16822

64350

$1 \quad 13417$

62119

13517

8769

5

9895

$\begin{array}{r}87662 \\ 30094 \\ \hline R 117756\end{array}$

84405

28688

R113093

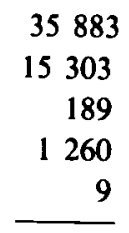

11

12

2987

1640

36083

16157

396

1260

4

R 52644

R 53900

20642

1602
13

14

42562

49372

49372

3378

95312

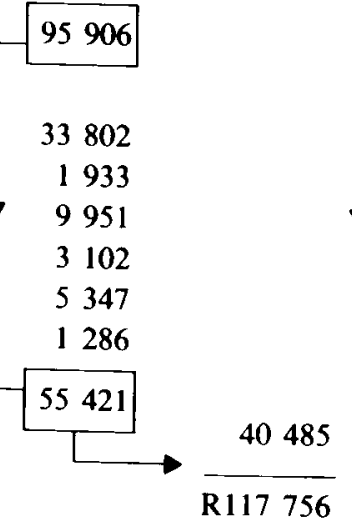


systematic arithmetic, and acceptable unidirectional motion, certain figures are counted upwards. This makes for inconsistency and the fact that this queer system has become of widespread use, nonetheless neither adds to its logic nor explains its illogic. The way figures are currently presented make balance sheets a dark jungle of collations in which the normal reader is cruelly shunted backwards and forwards an unorthodox dusky jungle in which he not only loses his sense of direction and tends to lose his way, but in which, he also gets toughly entangled. After all, balance sheets should be self-explanatory and not be so complicated that they require to be explained a priori. It should be realized that any document or book is read from the top downwards not vice versa. The current 'modern' system could have been justified if there were not a better alternative system of presentation.

\section{Recommendations}

\section{Use of columns}

This whole question of presenting financial statements can be easily overcome by the artful application of columns.

With figures rounded off the question of space presents very little of a problem.

An alternative way of presenting the figures in the above example are shown in Figure 3.

The suggested alternative manner of presentation does away with the intolerable gimmick of boxes.

\section{Guard against a profusion of notes}

Notes are necessary indeed but the problem about them is that one must page backwards and forwards when reading the financial statements. Therefore, inasmuch as notes can be incorporated in the actual figures in the balance sheet itself, without causing the statements to be cumbersome it is felt that they should be so included. An undue proliferation of notes should be guarded against.

\section{Conclusion}

The points of criticism voiced above are intended to be constructive and not destructive. It should be realized that annual financial statements are not an end by themselves but merely an informational aid or tool to serve managerial purposes.

'In their main structure accounts should be stated in language which requires only a minimum of special training for their full interpretation and they should be reasonably intelligible to laymen' (Bray and Sheasby, 1947).

The accounting world would no doubt do well to heed the above authoritative comment and to rethink their structuring of financial statements. The accounting profession is there to serve and not to dictate. Therefore, instead of unnecessarily complicating the way of presenting financial staternents, please keep it simple - the 'KISS' principle in management. The profession requires to wrest itself from the unmitigated accounting jungle of their own creation. Alternatively, must one conclude that accountants are a special species of prescriptive creatures with a peculiar mind of their own, immune to corrective criticism and incapable of being convinced for the better?

\section{References}

Bray, F.S. \& Sheasby, H.B. 1947. Design of Accounts. 2nd Edition. London: Oxford University Press.

Government Printer. 1941. Companies Act No 46 of 1926. Pretoria.

Henochsberg, E.S. \& Fairbairn, W.J.G. 1953. Henochberg on the Companies Act. Durban: Butterworth \& Co. (Africa).

Hutchinson, G.A. \& Tunstall, F.C. 1926. Practical Bookkeeping for South African Students. 2nd Edition. Cape Town: Mercantile Press.

National Council of Chartered Accountants. 1978. Statements of Generally Accepted Accounting Practice. Johannesburg.

Schoeman, T. 1973. Guide to the Companies Act and Regulatings, Cape Town: Juta \& Co., Ltd., Section 286 (3), $10-129$.

Wulfsohn, B. \& Carter, R.N. 1947. Advanced Accounts. 3rd Edition. London: Pitman \& Sons, p.1. 